
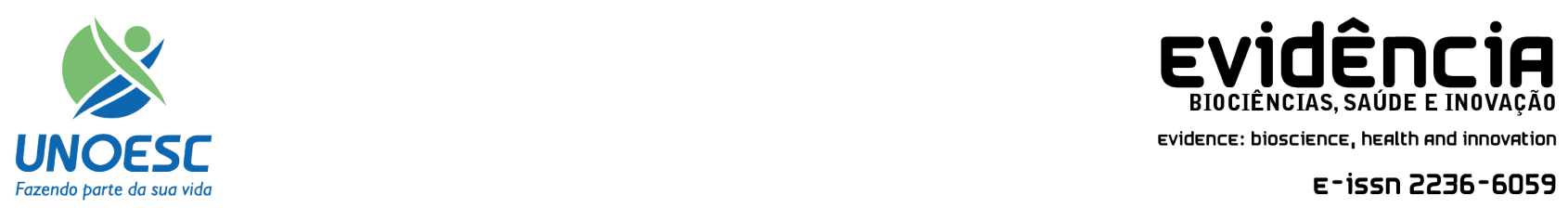

EDITORIAL

https://doi.org/10.18593/eba.29721

É uma honra e uma satisfação anunciar o primeiro volume de 2021 da Revista Evidência: Biociências, Saúde e Inovação, vinculada ao Programa de Pós-Graduação em Biociências e Saúde (PPGBS) da Universidade do Oeste de Santa Catarina (Unoesc).

Como de costume, o presente volume conta com artigos científicos divididos nas três áreas de concentração do periódico.

Na seção Biociências, apresentamos dois artigos originais com conteúdo bastante pertinente para a área de alimentos. O primeiro tem como título "Avaliação da qualidade microbiológica de queijos coloniais comercializados em feira livre na cidade de Fraiburgo, SC". Os queijos coloniais são importantes produtos alimentícios comercializados na região, sendo pertinente avaliar as condições adequadas de armazenamento e a potencial presença de patógenos. Infelizmente, foi constatado que há uma quantidade considerável de produtos em não-conformidade com as diretrizes sanitárias vigentes.

O segundo artigo, intitulado "Óleo de eucalipto para frangos de corte: titulação de anticorpos em resposta à vacinação contra bronquite infecciosa e efeitos antioxidantes", teve como objetivo avaliar o potencial do óleo de eucalipto administrado na água de beber ou nebulização sobre a titulação de anticorpos da bronquite infecciosa nas aves, não tendo sido encontradas alterações.

A seção Saúde conta com dois estudos. O primeiro é um estudo de coorte retrospectivo intitulado "Perfil clínico e microbiológico da infecção no pé diabético por bactérias carbapenêmico-resistentes em um hospital do sul do Brasil". O estudo, redigido em inglês, envolveu pacientes diabéticos que foram submetidos a amputação ou desbridamento, sendo analisado o perfil epidemiológico e microbiológico dos pacientes, concluindo que infecções por bactérias carbapenêmico-resistentes não parecem estar associadas a desfechos mais graves, apesar do tópico merecer atenção pelas limitações terapêuticas associadas.

O segundo artigo desta seção, "Custo direto do pré-natal na atenção primária a saúde”, traz uma estimativa sobre qual é o investimento realizado para a viabilização do pré-natal de puérperas, tendo como base os procedimentos realizados por 19 gestantes, indicando um investimento médio de $\mathrm{R} \$ 183,91$. Este é um conhecimento de grande relevância, uma vez que se refere a um dado de gestão de dinheiro público para um programa com um grande impacto positivo na saúde populacional.

Por fim, a seção Inovação conta com uma revisão que traz um interessante panorama sobre as aplicações da erva-mate (Ilex paraguariensis) em alimentos. O artigo "Aplicabilidade de extratos de erva- 
mate (Ilex paraguariensis) em diferentes alimentos", publicado em inglês, demonstra a versatilidade do produto, já tendo sido testado para uma vasta gama de aplicações alimentícias, apesar de muitas ainda não terem sido avaliadas em uma situação de mercado.

Em nome de toda a equipe da Revista Evidência: Biociências, Saúde e Inovação, agradeço aos autores por terem escolhido nosso periódico como o veículo de publicação de suas produções acadêmicocientíficas, que são a razão de ser de nosso trabalho. Agradeço, também, aos Avaliadores por seu tempo e interesse em colaborar com nossa publicação, dividindo seu conhecimento e garantindo a qualidade dos trabalhos submetidos. Que nosso periódico, com sua natureza open-access, tenha sucesso ao contribuir na jornada acadêmica de todos envolvidos e servindo como um valioso meio de disseminação de conhecimento. Por fim, e não menos importante, agradeço aos meus pares, os outros membros da equipe editorial da Evidência, pela oportunidade concedida a mim para participar desse belo trabalho ao longo da elaboração desta edição e poder, como o mais novo membro da equipe editorial, com muito orgulho poder ser o autor deste documento.

Desejo a todos uma boa leitura.

Cordialmente, Dr. Marcos F. Cordeiro

\section{Corpo editorial:}

Dra. Aline P. Remor, Editora-Chefe

Dr. Diego de Carvalho, Editor-Assistente

Dr. Marcos F. Cordeiro, Editor-Assistente 